\title{
Evaluation of Rootstocks for Temperate Fruit Crops-A Review
}

\author{
Jyoti Bharti Sharma*, Nidhi Chauhan, Kanchan Rana and Manish Bakshi \\ Department of Horticulture, School of Agriculture, Lovely Professional University, \\ Phagwara, Punjab, India \\ *Corresponding author
}

\section{A B S T R A C T}

\begin{tabular}{l} 
K e y w o r d s \\
$\begin{array}{l}\text { Rootstocks, } \\
\text { Evaluation, Biotic } \\
\text { and Abiotic factors, } \\
\text { Chilling } \\
\text { requirement }\end{array}$ \\
Article Info \\
$\begin{array}{l}\text { Accepted: } \\
\text { 24 October } 2020 \\
\text { Available Online: } \\
\text { 10 November } 2020\end{array}$ \\
\hline
\end{tabular}

Susceptibility to biotic and abiotic factors is the major concern in the temperate fruit crops which leads to the reduction in yield, poor quality of fruits, and sometimes the unproductiveness and death of the entire tree. Therefore, using suitable rootstocks for propagation plays a key role in enhancing the longevity of the orchard and help in fetching beautiful market price. In Temperate areas, winters are more severe as compared with the summers so, the evaluation of such rootstocks which are tolerant to cold and have higher chilling requirements is the most important prospect besides other known issues. The efficacy of a fruit orchard can be enhanced by combining two different plant parts of interest using budding and grafting some desirable characters for which a rootstock is being exploited are precocity, proliferate bearing, size control, and resistance against unfavorable conditions. Also, it exhibits some other effects on the scion cultivars in terms of performance. This review has focused only on some important fruit crops and describes the selection and evaluation of important rootstocks to increase the productivity of temperate fruit crops.

\section{Introduction}

Rootstock is the underground part of the plant that comprises the root portion, on which the scion wood or bud of a desirable cultivar is placed by the method of grafting and budding. As the name suggests itself, rootstock consists of a strong root system and is hardy. Rootstocks are propagated through both seeds or by vegetative means. The stocks which are prepared from seeds are called seedling rootstocks and later are called clonal rootstocks. Based on performance, clonal rootstocks are highly preferred than the seedling rootstocks but they have short life cycles. Before selecting the rootstock, one should know all the parameters of it, as well as the area where it is going to be cultivated. For temperate fruit crops, such rootstocks should be evaluated which have a higher ability to withstand the cold temperature in winters. Different rootstocks possess diverse properties such as resistance to cold, drought, salinity, pests \& diseases, etc., and impart the effects like tree vigor, precocity, and fruit size on the scion cultivars.

In addition to these properties, a rootstock must be compatible with the scion varieties and for this purpose; mostly the plants of the 
same family are used as rootstocks. Evaluation for desired traits starts from the nursery and the plants with the appropriate characters are selected and multiplied for rootstocks. However, some wild rootstocks also consist of some major qualities like hardiness and used for grafting purposes. The temperate fruit crops, for which the rootstocks are used are apple, pear, plum, peach, apricot, cherry, walnut, etc.

\section{Evaluation of rootstocks of important temperate fruit crops based on resistance, yield, and other quality parameters}

\section{Apple rootstocks}

Among all the temperate fruit crops, apple is most important and proved as a cash crop for the temperate fruit growers. Several rootstocks have been selected and bred so far by the apple rootstock breeding program at HRI, East Malling but they are not always satisfying the needs of the modern apple growers and are not adaptable for every region (Webster, 1992). Therefore, the need for developing and identifying potential rootstocks is always there. Quamme and Brownlee (1996) conducted three studies to identify the rootstocks with cold hardiness and observed the minimum survival temperature (MST) of the rootstocks in terms of browning of xylem and phloem. The roots of the plants were frozen with $1{ }^{\circ} \mathrm{C}$ temperature/hour to check the cold resistance. In the first study, the MST of M26 $\left(-10.0^{\circ} \mathrm{C}\right)$ was observed lower followed by MM106 ($\left.7.2^{\circ} \mathrm{C}\right)$ and $\mathrm{M} 7\left(-6.7^{\circ} \mathrm{C}\right)$ budded with Golden Delicious and Heyer12. In the second study, Summerland McIntosh variety was used as scion and the average MST of P. $2\left(-13.3^{\circ} \mathrm{C}\right)$ and Ottawa $3 \mathrm{I}\left(-13.2^{\circ} \mathrm{C}\right)$ was significantly lower followed by B9 $\left(12.3^{\circ} \mathrm{C}\right)$, Jork 9 ($\left.11.8^{\circ} \mathrm{C}\right)$, Alnorp $2\left(-11.2^{\circ} \mathrm{C}\right)$ than the M9 ($\left.9.6^{\circ} \mathrm{C}\right)$ and $\mathrm{M} 7\left(-7.6^{\circ} \mathrm{C}\right)$. In another study, Robusta 5 exhibits great hardiness than M7,
M26, and B9 on the Summerland McIntosh variety. Comparing the cold hardiness among the Malling series, (M7,9.26,104 and 106), M26 reported more tolerant against cold temperature under snow cover whereas, M7 was least tolerant (-7.6) and get killed (Wildung et al., 1973). Among the Geneva series (Moran et al., 2011), the cold hardiness of root tissues in Geneva 935 is reported more, whereas the G11, G30, G41 are equal hardy to M26. The selection of new dwarfing rootstocks with high tolerance to cold temperature has been made by various rootstock breeding programs in the USA (Cummins and Aldwinckle, 1983), Poland (Zagaja, 1980), Sweden (Trajkovski and Andersson, 1988), and Canada (Gragner et al., 1992).

Tolerance against drought condition is a desirable trait, imparted by the gene MdDREB76 which encodes a functional transcription factor. Drought tolerance in the rootstock is determined by the root dry mass (Christopher J. Atkinson et al., 1998). Out of all $\mathrm{M}$ and $\mathrm{MM}$ series rootstocks, M9 was found to have higher numbers of coarse roots. Whereas, among the new selection from HRIEast Malling (AR69-7, AR295-6, AR360-19, AR486-1, and AR628-2), dwarfing rootstock AR295-6 produces the most course roots which are three times or more than that of the M9. Similarly, the large numbers of fine roots are also found in dwarfing clone AR295-6. Because of the higher root mass, the plant can absorb more water and can withstand the drought conditions.

Tolerance to salt in apple is also controlled by the same gene MdDRE76. Motosugi et al., (1987) compared the salt tolerance between 9 rootstocks of apple (Malusprunifolia, M4, M7, M9, M11, M16, M26, M27, and MM106), out of which M4 and M11 were severely affected by salt injury whereas, M26 was least affected. Between two In-vitro 
cultured rootstocks MM106 and Omara (Abdel-Hussein, 2003), MM106 was found most tolerant to salinity condition. Since wooly apple aphid infestation is a major problem in apple, all the rootstocks of Malling series of apple are susceptible to the wooly apple aphid whereas, all the MM series are resistant to it but MM 106 is very sensitive for the phytophthora infestation which causes the collar rot. Dwarfing rootstocks (Nicole L. Russo et al., 2007) Geneva ${ }^{\circledR}$ 935, G41, G11, and B.9 are resistant to fire blight and phytophthora root rot with increased yield efficiency. Similarly, rootstocks M9, EMLA, Mark, Bud 118, and Bud 9 are also reported resistant to Phytophthoracactorum.

\section{Pear rootstocks}

Unlike apple, rootstocks for pear have not been developed in numbers because of the less adaptability. It is still grafted on the rootstocks (Bartlett, Anjou, etc.), which are of seedling origin resulting in extreme vigor, long juvenile phase, and variable yields. There are several other species of Pyrus which are used as rootstocks such as Pyruspyrifolia, Pyruspashia, P. betulifolia, $P$. calleryana, P. ussuriensis (Webster, 1997) but they impart in vigorous growth on scion variety, therefore, are not very popular. Among the seedling rootstocks, $P$. betulifolia is tolerant to salinity (Okubo et al., 2000) and can grow better even in the soils with a higher concentration of $\mathrm{NaCl}(50 \mathrm{mM})$. A clonal rootstock Quince (Cydonia oblonga Mill.) is the popular rootstock for pear which imparts the dwarfness and precocity but there is the problem of poor graft compatibility. To overcome this problem, some interstocks which are graft compatible (e.g. Beurrè Hardy) should be used. Also, Quince is very sensitive to cold \& alkaline $\mathrm{pH}$ and has very poor anchorage with soil as compared to the seedling rootstocks. Various dwarfing clones of Quince rootstocks have been developed such as Quince A, Quince C (HRI, East Malling), BA29, Sydo (INRA, France), Adams 332 (Belgium), and CtS.212, (Pisa, Italy). Quince C is more dwarfing (10-20\%) than Quince A. In the nurseries as well as orchards, Sedo performs better than the Quince A whereas, Adams 332 is preferred more by the nurserymen. Rootstock CtS.212 has found more tolerant of the soils with high pH (Loreti et al., 1997). A new dwarfing rootstock 193-16 selected from East Malling, in combination with scion gives rise to fruits with large size and also imparts the precocity (Browning and Watkins, 1991). The rootstocks of the OHF series are most popular (Brooks, 1984) but the problem lies with them is large tree vigor, due to which they are not preferred for high-density orcharding. However, OHF 333 and OHF 59 are less vigorous than the other clonal rootstocks of the OHF series. OHF 87 is reported high yielding and is resistant to fire blight (Erwinia amylovora) and tolerant to pear decline.

\section{Peach and Nectarine Rootstocks}

Traditionally, Peaches and nectarines were mostly grafted on their seedlings but these rootstocks have several problems like late bearing, variability, vigorous growth, etc. Peaches are very prone to nematode attacks and are severely affected by several soil nematodes such as Meloidogyne spp., Pratylenchus spp., Xiphinema americanum, and many soil-borne pathogens like Phytophthora spp., Armillaria spp., Verticillium spp., Agrobacterium tumefaciens, etc. So, the major focus is on producing the rootstocks which are resistant to these pests. Rootstocks such as Nemaguard, Nemared, Flordaguard, and Guardian have been reported resistant to most of the species of root-knot nematode. Similarly, the tolerant rootstocks (Alcaniz et al., 1996) to lesion nematode (Pratylenchus penetrans and $P$. 
vulnus) and Xiphinema americanum have also been reported from different countries namely Rubira (French), Penta, Tetra (Italian), and Torinel (Spanish). Apart from sensitivity to nematodes, peaches are also non-adaptable to heavy soils with poor drainage and the calcareous soils. Therefore, the hybrid rootstocks from various places have been developed and proved tolerant of calcareous soils. These hybrid rootstocks are namely Barrier 1, Sirio (Italian), Julier, Paramount, Jasper, Cadaman (French), T 16 (Romanian), and Spanish rootstocks Montizo, Adarcias, and Adesoto 101 (Moreno et al., 1995). Hybrids between the peach and almond $(P$. dulcis) such as Monegro, Pema, Paramount, Garnem, and peach $\times P$. davidiana namely Barrier 1, PeDa, and Cadman have been reported drought tolerant. Similarly, Everica 99, VVA-1, Kuban 86, and VSV-1 (Krymsk Fruit Research Station, Western Russia) are the 4 new rootstocks that have been found cold hardy. Besides these, Tetra, Rubira, P.S. A5, Everica, and Junior are mildly dwarfing rootstocks.

\section{Plum rootstocks}

Unlike other fruit crops, a few clonal rootstocks have been developed for plum and most of the plum varieties are grown on the seedlings of Myrobalan ( $P$. cerasifera), whereas the clonal selections from St. Julien are most popular in UK, Scandinavia, and Holland. Plum pox virus is a serious disease in plum which results in great yield loss. Hybrid Myrobalan 29C (Almond x peach) and L2 cherry are reported resistant to plum pox virus and do not show any symptoms of virus infection (Manuel Rubio et al., 2005). Rootstock Mr. S. 2/5 has found tolerant to waterlogging condition and alkaline soils, whereas the clonal rootstock ISG $1 / 5$ has reported tolerant to lime induced chlorosis (Cinelli and Loreti, 2002). Some new selections such as Mariana GF 8/2, Mariana
8-6 (Maridon), Mariana 2624, Myrabi, Adara, Myrobalan 29C, etc. are however vigorous but show resistance against some specific soil problems. Whereas, Pixy, Maridon, and Ferlenain are dwarfing rootstocks and are suitable for HDP (Webster and Werthein, 1993).

\section{Apricot Rootstocks}

Apricot (Prunus armeniaca L.) is grown worldwide and grafted mostly on the seedling rootstocks. Most of the seedling rootstocks used for apricot belongs to the same species. Seedlings of peach are also used as rootstocks for apricots but are not much popular. Many apricot varieties are also grafted on Myrobalan seedling rootstock and its clones (Myrobalan B, Myrobalan 29C) throughout the apricot producing areas. Rootstocks such as Mariana GF 8-1, Greengage CD-4 and Damas1869 are reported to give higher yields in combination with scion varieties (Dimitrova, 2003). The rootstock Mariana GF 8-1 also contributes to increasing the longevity of the tree. A Spanish rootstock Pollizo prune (Prunusinstitia L.) has been found resistant to the flooding condition on the Mediterranean coast of Spain (Rafael Domingo et al., 2002). Viruela is a serious viral disease of apricot in Spain which is caused by the Apple Chlorotic Leaf Spot Virus (ACLSV). Studies have been reported that two rootstock selections namely GF305 peach and Real Fino apricot seedlings are resistant to ACLSV and did not show any symptom of disease on the leaves (Ibarra et al., 2010).

\section{Cherry rootstocks}

There are two species of cultivated cherries i.e. sweet cherry (Prunus avium) and sour cherry (Prunus cerasus) which are grown all over the world. Sweet cherries are mostly used for fresh consumption, whereas the tart 
or sour cherries are utilized mainly for processing purposes. Sweet cherries are grafted on the rootstocks of their species but impart vigorous growth therefore, are not suitable for high-density planting. Two rootstocks Mazzard (wild sweet cherry) and $P$. mahaleb (St Lucie) are the most popular rootstocks of cherry but they also don't contribute to size control. Four clonal rootstocks Z1, PN, P3, and P7 (Lanauskas et al., 2004) for sweet cherry (Vytenu rozine) were evaluated for yield and other field parameters at the Lithuanian Institute of Horticulture. Among all 4 rootstocks, P3 resulted in highest productivity, whereas the lowest was recovered from the Z1 and P7. However, PN rootstock gave average productivity but did not produce suckers, whereas the P3 showed profuse suckering. Colt is a very popular and old rootstock originated in Kent, England, and is a hybrid between $P$. avium F 299/2 x P. pseudocerasus L. It is semi vigorous, resistant to Phytophthora root rot, field stem pitting, and is compatible with almost all the varieties of sweet and sour cherry. Among Colt, Stockton Morello (SM), and SL-64 (Toribioet al., 1997), SM is reported to give higher yield and produces small trees and the lower yield is recovered from SL-64. Semi-dwarf rootstocks of cherry (e.g. Maxma-14, Colt) induce the precocity but their branches form the blind wood very easily. A large number of dwarfing rootstocks have also been identified, including mainly the Edabriz and Weiroot series which are mostly the selections from the species of sour cherries or some closely related species.

It is concluded from the above study that most of the varieties of fruit crops are grafted on the seedling rootstocks except apple which is largely propagated through the clonal rootstocks. Being the members of a singlefamily, similar rootstocks are also used for some stone fruits. Every rootstock consists of specific traits and has certain advantages and disadvantages. It has been noted that every rootstock is not adaptable to all the temperate areas because of the variability in soil. Therefore, there is further need for developing such potential rootstocks which could be adapted in almost all the temperate fruit growing belts to sustain the quality of fruits.

\section{References}

Abdelhussein, M. A. A. (2006). Evaluation of MM106 and Omara apple rootstocks for salt tolerance in vitro. Journal of Kerbala University, 1(1): 178-185.

Alcañiz, E., Pinochet, J., Fernández, C., Esmenjaud, D., \& Felipe, A. (1996). Evaluation of Prunus rootstocks for rootlesion nematode resistance. HortScience, 31(6): 1013-1016.

Brooks, L. A. (1984). History of the Old Home X Farmingdale pear rootstocks. Fruit Varieties Journal 38: 126-128.

Atkinson, C. J., Policarpo, M., Webster, A. D., and ArboreeA. M. (1999). Drought Tolerance of Apple Rootstocks: production and partitioning of dry matter. Plant and Soil 206: 223-235

Cinelli, F., and Loreti, F. (2002). Evaluation of Some Plum Rootstocks concerning Lime Induced Chlorosis by Hydroponic Culture. I International Symposium on Rootstocks for Deciduous Fruit Tree species 658: 421-427.

Cummins, J. N., and Aldwinckle H. S. (1983). Breeding apple rootstocks. Plant breeding reviews pp 294-394

Wildung, D. K., Weiser, C. J., and Pellett H. M. (1973). Cold Hardiness of Malling Clonal Apple Rootstocks Under Different Conditions of Winter Soil Cover. Canadian Journal of Plant Science 53(2): 323-329.

Dimitrova, M. (2001). Evaluation of some plum rootstocks as rootstock for apricot in the orchard.VII International Symposium on Plum and Prune Genetics, Breeding and Pomology 577: 311-314.

Domingo, R., Pérez-Pastor, A., and Ruiz-Sánchez, M. C. (2002). Physiological responses of apricot plants grafted on two different rootstocks to flooding conditions. Journal 
of Plant Physiology 159(7): 725-732.

Debbagh, N. E. I. (2016). Analyse de la diversité de processus de développementracinaire chez les Prunus: aptitude au bouturage et réponses à la contraintehydrique (Doctoral dissertation). (Doctoral dissertation, Universitéd' Avignon).

Toribio, F., Moreno, J., and Manzano, M. A. (1997). Evaluation of Rootstocks for Cherry Trees. III International Cherry Symposium 468: 339-344.

Romera, F. J., Alcantara E., and Guardia, M. D. D. L. (1991). Characterization of Drought Tolerance to Iron Chlorosis in Different Peach Rootstocks Grown in Nutrient Solution. Iron Nutrition and Interactions in Plants, 145-149.

Francescatto, P., Pazzin, D., GazollaNeto, A., Fachinello, J. C., andGiacobbo, C. L. (2010). Evaluation of graft compatibility between quince rootstocks and pear scions. Actahorticulturae 872: 253-259.

Sottile, F., Signore, M. B. D., Massai, R., Capocasa, F. and Mezzetti, B. (2012). Rootstock Evaluation for European and Japanese Plums in Italy.Acta Hort. 968.

Browning, G., and Watkins, R. (1991). Preliminary Evaluation of New Quince (Cydonia oblonga Miller) hybrid Rootstocks for Pears. Journal of Horticultural Science 66 (1): 35-42.

Browne, G. T., and Mircetich, S. M. (1993). Relative Resistance of Thirteen Apple Rootstocks to Three species of Phytophthora. Phytopathology 83: 744-749.

Ibarra, A. G., Rubio, M., Dicenta, F., and Gomez P. M. (2010). Evaluation of Resistance to Apple Chlorotic Leaf Spot Virus (ACLSV) in Controlled Greenhouse Conditions in Apricot Breeding Programme of CEBASCSIC in Murcia (Spain). ActaHorticulturae 862: 487-490.

Granger, R. L.,Rouselle, G. L., Meheriuk, M., and Khanizadeh, S. (1992). Performance of 'Cortland' and 'McIntosh' on fourteen rootstocks in Quebec. Fruit Varieties Journal 46:114-118.

Reighard, G. L. (2002). Current Directions of Peach Rootstock Programs Worldwide.Acta Hort. 592.

Quamme H. A., and Brownlee, R. T. (1996). Cold
Hardiness Evaluation of Apple Rootstocks. VI International Symposium of Integrated Canopy, Rootstock, Environmental Physiology in Orchard System, ActaHorticulturae 451: 187-194.

Motosugi, H., Sugiura, A., and Tomana, T. (1987). Salt Tolerance of Various Apple Rootstock Cultivars. Jpn. Soc. Hort. Sci. 56: $135-141$

Lanauskas, J., Kviklys, D., and Uselis, N. (2004). Evaluation of Rootstocks for Sweet Cherry cv. 'Vytenurozine'. International Symposium on Canopy, Rootstock and Environmental Physiology in Orchard Systems 732: 335-339.

Loreti, S., Faggioli, F., and Barba, M. (1997). Identification and characterization of an Italian isolate of pear blister canker viroid. Journal of Phytopathology, 145(11-12), 541-544.

Gyevivi, M., Bujdoso, G., and Hrotko, K. (2008). Results of Cherry Rootstock Evaluation in Hungary. International Journal of Horticulture Science 14(4): 11-14.

Moreno, M. A. (2002). Breeding and Selection of Prunus Rootstocks at Aula Dei Experimental Station, Zaragoza, Spain. ProcIst IS Rootstocks - Decid. Fruit 658: 519-528.

McAfee, J. D., and Rom, C. R. (2003). Evaluation of size-controlling apple rootstocks for high-density 'Gala'apple orchards in Arkansas: final year results of the 1994 NC140 uniform apple rootstock trial. Hort. Studies, 21-23.

Moran, R. E., Sun, Y., Geng, F., Zhang, D., \& Fazio, G. (2011). Cold temperature tolerance of trunk and root tissues in one-or two-year-old apple rootstocks. HortScience, 46(11), 1460-1464.

Okubo, M., Furukawa, Y., and Sakuratani, T. (2000). Growth, flowering and leaf properties of pear cultivars grafted on two Asian pear rootstock seedlings under $\mathrm{NaCl}$ irrigation. Scientia horticulturae 85(1-2): 91-101.

Parad, G. A., Zarafshar, M., Striker, G. G., and Sattarian, A. (2013). Some physiological and morphological responses of Pyrusboissieriana to flooding. Trees 27(5): 1387-1393. 
Rubio, M., Martínez-Gómez, P., Pinochet, J., andDicenta, F. (2005). Evaluation of resistance to sharka (Plum pox virus) of several Prunus rootstocks. Plant Breeding 124(1): 67-70.

Russo, N. L., Robinson, T. L., Fazio, G., and Aldwinckle, H. S. (2007). Field evaluation of 64 apple rootstocks for orchard performance and fire blight resistance. HortScience 42(7): 1517-1525.

Russo, N. L., Robinson, T. L., Fazio, G., and Aldwinckle, H. S. (2007). Field evaluation of 64 apple rootstocks for orchard performance and fire blight resistance. HortScience, 42(7): 1517-1525.

Sharma, V., Goel, P., Kumar, S., and Singh, A. K. (2019). An apple transcription factor, MdDREB76, confers salt and drought tolerance in transgenic tobacco by activating the expression of stressresponsive genes. Plant cell reports 38(2): 221-241.

Toribio, F., Moreno, J., and Manzano, M. A. (1997). Evaluation of rootstocks for cherry trees. III International Cherry Symposium 468: 339-344.

Trajkovski, V., and Andersson, G. (1988). Stone fruit breeding. In: Verksamhetsberattelse 1986-87. Report SLU - Balsgard, pp 16-23.

Vachun, Z. (1993). Rootstocks for apricot-the current situation and main problems. In $X$ International Symposium on Apricot Culture 384: 459-466.

Warschefsky, E. J., Klein, L. L., Frank, M. H., Chitwood, D. H., Londo, J. P., von
Wettberg, E. J., and Miller, A. J. (2016). Rootstocks: diversity, domestication, and impacts on shoot phenotypes. Trends in plant science, 21(5): 418-437.

Webster A.D. (1998). A Brief Review of Pear Rootstock Development. Horticulture Research International, East Malling, West Malling, Kent, ME196BJ UK.

Webster, A. D. (1992). New dwarfing rootstocks for apple, pear plum and sweet cherry-a brief review. In V International Symposium on Orchard and Plantation Systems 349: 145-154.

Webster, A. D., and Wertheim, S. J. (1993). Comparisons of species and hybrid rootstocks for European plum cultivars. Journal of Horticultural Science68(6): 861869.

Webster, T., Tobutt, K., and Evans, K. (2000). Breeding and Evaluation of New Rootstocks for Apple, Pear, and Sweet Cherry. Compact Fruit Tree 33(4): 100104.

Wildung, D. K., Weiser, C. J., andPellett, H. M. (1973). Cold hardiness of Malling clonal apple rootstocks under different conditions of winter soil cover. Canadian Journal of Plant Science 53(2): 323-329.

Zagaja, S. W. (1980). Performance of two apple cultivars on $\mathrm{P}$ series dwarf rootstocks. In Symposium on Research and Development on Orchard and Plantation Systems 114: 162-169).

\section{How to cite this article:}

Jyoti Bharti Sharma, Nidhi Chauhan, Kanchan Rana and Manish Bakshi. 2020. Evaluation of Rootstocks for Temperate Fruit Crops-A Review. Int.J.Curr.Microbiol.App.Sci. 9(11): 35333539. doi: https://doi.org/10.20546/ijcmas.2020.911.422 